\title{
A DEMOCRACIA E A JUDICIALIZAÇÃO DOS DIREITOS SOCIAIS
}

\author{
Winston de Araújo Teixeira ${ }^{1}$
}

\section{RESUMO}

O presente artigo objetiva analisar o conceito de democracia assim como a judicialização dos direitos sociais. Para delimitar o conceito serão utilizadas as acepções de filósofos, cientistas políticos e juristas, dentre eles, Platão, Strauss, Popper, Tocqueville, Mill, entre outros. Para atingir o objetivo proposto utiliza-se a revisão bibliográfica e o método dedutivo, cujas bases teóricas são a doutrina da efetividade e a dogmática dos direitos sociais, além da discussão sobre as objeções à crescente intervenção judicial na garantia dos direitos fundamentais, principalmente, aqueles que são denominados direitos sociais.

Palavras-chave: Democracia. Estado Democrático de Direito. Judicialização. Ativismo Judicial. Direitos Sociais

\section{DEMOCRACY AND JUDICIALIZATION OF SOCIAL RIGHTS}

\begin{abstract}
This article aims to analyze the concept of democracy as well as the judicialization of social rights. To delimit the concept will be used the meanings of philosophers, political scientists and jurists, among them Plato, Strauss, Popper, Tocqueville, Mill, among others. To achieve the proposed objective we use the literature review and deductive method, whose theoretical bases are the doctrine of effectiveness and the dogmatic of social rights, in addition to the discussion about the objections to the increasing judicial intervention in guaranteeing fundamental rights, especially those which are called social rights.
\end{abstract}

Keywords: Democracy. Democratic state. Judicialization. Judicial activism. Social rights

\section{INTODUÇÃO}

A democracia teve seu apogeu na Grécia clássica, mas foi renegada ao esquecimento após a derrota de Atenas na Guerra do Peloponeso. Com o surgimento do Iluminismo a democracia reconquista seu espaço e, atualmente é considerada o melhor regime político. Acontece que não há um consenso quanto a importância da democracia enquanto regime político, por isso, torna-se fundamental estudar as implicações da democracia.

De início deve-se compreender a distinção entre os regimes, para tanto, recorre-se à filosofia política que oferece teorias sobre o melhor regime (STRAUSS, 2008). Nessa esteira

\footnotetext{
${ }^{1}$ Doutorando em Ciências Jurídicas com concentração em Direitos Humanos pelo PPGCJ/UFPB. Mestre em Direito com concentração em Processo e Garantia de Direitos pelo PPGD/UFRN. Professor do NPJ/UFAM. Professor da Faculdade Estácio do Amazonas. Advogado. winstonteixeira@ufam.edu.br
} 
de pensamento pode-se utilizar a ideia de Platão, na obra República, que afirma ser o melhor regime aquele que pode ser considerado mais justo, o problema então passa pela definição de justiça. Para a maioria dos democratas, a justiça é alcançada quando há a possibilidade de participação nos assuntos públicos e nos processos que resultam em decisões políticas.

É importante mencionar que da democracia pode surgir a anarquia ou a tirania, não pela impotência do regime, mas pelo abuso das forças democráticas e do mal emprego de seus recursos. O poder que governa a sociedade não é estável. Por isso, é necessário ponderar a atuação dos representantes do Estado, a fim de evitar exageros, já que todo poder emana do povo e seu controle deve ser preservado pelo Estado.

Para promover o balanceamento da atuação estatal e o exercício da liberdade individual cria-se o judiciário, que por sua vez representa a possibilidade de controlar o abuso de poder estatal, assim como a garantia dos direitos e liberdades fundamentais. Entretanto, na democracia, esse poder concedido ao judiciário também pertence ao povo e, por isso, deve ser limitado e controlado, até para evitar a interferência na área de atuação dos outros poderes.

O judiciário deve auxiliar o Estado na garantia dos interesses coletivos, na preservação das instituições democráticas e na efetividade dos direitos fundamentais, incluindo, os direitos sociais (saúde, trabalho, previdência, etc.), mas não deve interferir na atuação política reservada aos poderes legislativo e executivo, no âmbito, da elaboração e execução das normas, respectivamente, o que pode acarretar ampliação demasiada do poder judiciário, como ocorre no Ativismo Judicial.

\section{A DEMOCRACIA ENQUANTO REGIME POLÍTICO}

Há alguns anos a democracia brasileira vem sofrendo "ataques" substanciais, notadamente, no que tange aos direitos e garantias fundamentais, como é o caso dos direitos sociais. Nesse interim, o Estado brasileiro adotou uma conduta "reformista" e deu início a uma pulverização de ideias neoliberais que contradizem os ideais democráticos da República Federativa do Brasil.

A Constituição é considerada a norma fundamental de um Estado Democrático de Direito, segundo afirmações de Hans Kelsen e sua teoria da hierarquia das normas, entretanto, há várias discussões acerca do poder ou força normativa da constituição, vez que ora, ela não passa de uma 'folha de papel', facilmente alterável, ora representa a direção que o Estado 
deve seguir, impossibilitado de retroceder, garantindo um caráter mais rígido aos direitos consagrados naquela norma fundamental e, para Kant, há ainda uma norma hipotética fundamental acima desta carta política.

Enquanto isso, Lassalle defende que a Constituição não passa de uma folha de papel, que sozinha não possui valor normativo, mas a soma dos fatores reais de poder, ou seja, para ele, todos os membros da sociedade representam um fragmento da constituição, desde o rei e sua monarquia até os operários e a classe trabalhadora, razão pela qual o texto da carta política não tem poder normativo em decorrência da ausência ratificadora dos fatores reais de poder.

É fundamental compreender a essência da Constituição e, a partir de então, identificar se a Carta Política se acomoda ou não às exigências substanciais. (LASSALE, 2000, p. 06) Seguindo essa esteira de pensamento é possível compreender que a essência da constituição, representada pela vontade e pelo exercício cidadão das fontes reais de poder, direciona o Estado e suas políticas, que garantem ou violam os direitos fundamentais daquele povo, naquela época. No Brasil, de hoje, os fatores reais de poder são representados pelo grande mercado, pelas grandes empresas, pelo capitalismo liberal, pelos meios de comunicação de massa $^{2}$ (mídia), pelo ativismo judicial do poder judiciário que altera a Constituição ao invés de protege-la, além de outros que não interessam aos fins deste trabalho.

\begin{abstract}
Os aspectos que tenho em mente prendem-se ao fato de que, numa sociedade democrática, muitos membros lutam para elevar-se socialmente e tomar os lugares de outros membros. Isto pode levar, por exemplo, a um fenômeno social tão importante quanto a luta de classes. Não podemos encontrar nada de parecido à luta de classe num organismo. [...] Visto que não há nada no organismo que corresponda a uma das características mais importantes da sociedade democrática, a competição por posição entre seus membros, a chamada teoria orgânica do estado baseia-se numa falsa analogia. A sociedade fechada, por outro lado, não conhece muito tais tendências. Suas instituições, incluindo suas castas, são sacrossantas - tabus. (POPPER, 1988, p. 189)
\end{abstract}

No entanto, é importante recordar que no Estado Democrático brasileiro há uma ordem constitucional inquebrantável, que visa proteger o Estado e a sociedade contra o exercício ilegal desses fatores reais de poder, logo, não é possível atribuir apenas a estes a capacidade de constituir a norma fundamental do Estado, principalmente, porque, muitas vezes, a direção adotada confronta os interesses e a vontade da Constituição jurídica, que

\footnotetext{
${ }^{2} \mathrm{O}$ conceito de comunicação de massa utilizado nesse trabalho foi extraído do texto de THOMPSON, J. A mídia e a modernidade: uma teoria social da mídia. Petrópolis: Vozes, 2001.
} 
origina-se de três vertentes diversas. Baseia-se na compreensão da necessidade e do valor de uma ordem normativa inquebrantável, que proteja o Estado contra o arbítrio desmedido e disforme. Reside, igualmente na compreensão de que essa ordem constituída é mais do que uma ordem legitimada pelos fatos (e que, por isso, necessita de estar em constante processo de legitimação). Assenta-se também na consciência de que, ao contrário do que se dá com uma lei do pensamento, essa ordem não logra ser eficaz sem o concurso da vontade humana. Essa ordem adquire e mantém sua vigência através de atos de vontade. (HESSE, 1999, p. 12)

A Constituição Federal brasileira possui princípios rígidos cujo guardião é (ou deveria ser) o Supremo Tribunal Federal (STF), que por sua vez não podem ser flexibilizados em face da sua inquebrantabilidade, defendida por Hesse. Os princípios rígidos seguem a vontade e a força normativa da constituição, por isso, constituem uma ordem constitucional legítima, vez que está incutida na consciência geral. De igual modo, "os americanos reconheceram aos juízes o direito de fundar suas decisões na constituição, em vez de nas leis. Em outras palavras, permitiram-lhes não aplicar as leis que lhes parecerem inconstitucionais". (TOCQUEVILLE, 2005, p. 113)

Acontece que o Governo brasileiro vem tomando decisões que não condizem com a força normativa nem como o Estado Democrático de Direito, o que deslegitima as ações desenvolvidas, tendo em vista que o Governo deve ser a legítima direção do Estado, não podendo colidir com seus interesses, princípios rígidos e direitos fundamentais.

\footnotetext{
Mas o juiz americano é levado, independentemente de sua vontade, ao terreno da política. Ele só julga a lei porque tem de julgar um processo. A questão política que deve resolver prende-se ao interesse dos litigantes e ele não poderia se recusar a resolvê-la, sem cometer uma denegação de justiça. E cumprindo os deveres estritos' impostos a profissão do magistrado que age como cidadão. É verdade que, dessa maneira, a censura judiciária, exercida pelos tribunais sobre a legislação, não pode se estender sem distinção a todas as leis, porque há leis que nunca podem dar lugar a essa espécie de contestação nitidamente formulada que se chama processo. (TOCQUEVILLE, 2014, p. 116/117)
}

O Estado Democrático de Direito possui bases no positivismo de Kelsen, que defende a ideia da hierarquia normativa do ordenamento jurídico, fixando a norma fundamental como o pico da pirâmide do qual decorrem todas as outras normas, o que não ocorre com as reformas promovidas pelo governo brasileiro, que violam diretamente o ápice da pirâmide normativa, desregulamentando e flexibilizando direitos sociais fundamentais, que correspondem à vontade e compõem a força normativa constitucional. 


\begin{abstract}
A democracia é um trabalho árduo. Enquanto negócios familiares e esquadrões de exércitos podem ser governados por ordens, democracias exigem negociações, compromissos e concessões. Reveses são inevitáveis, vitórias são sempre parciais. Iniciativas presidenciais podem morrer no Congresso ou ser bloqueadas por tribunais. Todos os políticos se veem frustrados por essas restrições, mas os democráticos sabem que têm de aceitá-las. Eles são capazes de vencer a torrente constante de críticas. Para os outsiders, porém, sobretudo aqueles com inclinações demagógicas, a política democrática é com frequência considerada insuportavelmente frustrante. Para eles, freios e contrapesos são vistos como uma camisa de força. (LEVITSKY; ZIBLATT, 2018, p. 91)
\end{abstract}

Nesse sentido, a República de Platão ao narrar as ideias de Sócrates diz que a "democracia surge quando os pobres, tendo vencido os ricos, eliminam uns, expulsam outros e dividem por igual com os que ficam o governo e os cargos públicos. E, devo dizer, na maior parte das vezes estes cargos são atribuídos por sorteio". (PLATÃO, 1987, p. 361)

Esse pensamento consagra a teoria das lutas de classe, defendida por Marx, cuja ideia principal baseia-se na disputa entre trabalhadores (pobres) e empregadores (ricos), onde os ricos exploram a mão-de-obra dos pobres, obtêm lucro e mais-valia, enquanto os pobres adoecem e permanecem estagnados, submetidos e alienados ao sistema capitalista e ao consumo desenfreado. Pior é dizer que a situação acontece num Estado proclamado democrático. No entanto, a democracia não deve ser cinza, mas colorida, composta de todas as cores, e por isso deve ser considerada o mais belo de todos os regimes políticos. (PLATÃO, 1987, p. 362)

Infelizmente, há uma democracia conhecida como totalitária, que defende o surgimento de uma ideia democrática, fundada na soberania do povo, entendida como guia de uma atividade política que desconhece limites. Em nome da vontade popular, tudo seria possível, inclusive o desrespeito à lei e à Constituição ou, mesmo, a abolição das duas. (TALMON, 1956, p. 56)

Para Schumpeter (1984), um dos principais pontos dentro do conceito de democracia é que ela pode ser dividida e entendida de dois modos diferentes: a democracia burguesa (que garante as instituições livres e os direitos prescritos) e a democracia socialista (grande participação popular). No livro Capitalismo, Socialismo e Democracia, Schumpeter consegue apresentar uma nova forma de enxergar a democracia, apresentando a teoria competitiva da democracia, que auxiliam no entendimento dos diversos processos de modernização política, econômica e social. 
Segundo os estudos de Schumpeter (1984), a democracia pode ser entendida segundo uma lógica que toma como base alguns princípios fundamentais, que são os seguintes: Poder Executivo limitado pelo Poder Legislativo, exatamente como se vê no liberalismo clássico; Maior papel das lideranças políticas dentro do procedimento democrático; Maior cuidado e atenção em relação às vontades coletivas, que passam por um processo de vinculação entre interesses regionais, privados e círculos da opinião pública, criando um ambiente favorável; A democracia só irá funcionar por meio da competição e por meio da concorrência "livre pelo voto livre"; Equilíbrio entre as garantias das liberdades individuais e sociais com as instituições que conseguem legitimar essas liberdades; $\mathrm{O}$ eleitorado deve formar o governo, bem como dissolvê-lo, caso ele não entregue um trabalho qualificado e idôneo; A "vontade da maioria" é mais importante do que a "vontade do povo", mostrando a importância da representatividade.

Porque aí estão todas elas, graças à liberdade reinante, e parece que quem pretende fundar uma cidade, o que fazíamos há pouco, é obrigado a dirigir-se a um Estado democrático, como a um bazar de constituições, para escolher a que prefere e, a partir desse modelo, realizar em seguida o seu projeto. (PLATÃO, 1987, p. 362)

Assim, é possível afirmar que o futuro está na democracia representativa e no nacionalismo (STRAUSS, 2008, p. 54), já que a vontade do povo, em sua mais ampla representatividade, deve prevalecer na condução do Estado e das políticas públicas, razão pela qual a atuação dos representantes dos poderes Legislativo, Executivo e Judiciário não pode se sobrepor à vontade do povo.

O povo deve ser amo e senhor, sempre que quiser, de todas as atividades do governo, vez que o mecanismo político e as instituições políticas são obras dos homens, logo, representa uma questão de escolha. E essa escolha precisa promover o equilíbrio entre os interesses pessoais com o convencimento de pelo menos grande parte das pessoas que têm visões mais abrangentes. (MILL, 1981)

\section{A JUDICIALIZAÇÃO DOS DIREITOS SOCIAIS}

Aborda-se a tendência à judicialização do acesso aos direitos sociais, que cresceu em virtude da descrença da sociedade na atuação do Executivo, e da perda de credibilidade do Legislativo diante da inefetividade das normas por ele criadas e alteradas, o que acaba 
levando os indivíduos a recorrerem cada vez mais ao Judiciário para suprir as lacunas deixadas pelos demais poderes, caracterizando assim, uma modalidade de Ativismo Judicial, que se insurge como garantidor desses direitos, através do deferimento das demandas judiciais.

Deve-se notar que as mudanças sociais provocaram grandes avanços no ordenamento jurídico brasileiro, dentre eles o tratamento diferenciado das normas constitucionais, as quais passaram a ganhar maior efetividade mediante uma aplicabilidade imediata, muitas exigidas pela sociedade, através de ações judiciais, em face da inércia dos poderes Legislativo e Executivo, mediante alegações múltiplas, mas pouco convincentes ou plausíveis sob o ponto de vista dos sujeitos de direitos sociais.

\subsection{A DOUTRINA DA EFETIVIDADE DOS DIREITOS SOCIAIS}

Com o intuito de combater a definição dos direitos constitucionais sociais como meras normas programáticas ${ }^{3}$, a doutrina da efetividade busca tornar as normas constitucionais aplicáveis direta e imediatamente, na extensão máxima de sua densidade normativa, alcançando assim, sua eficácia plena, a fim de coibir esse comportamento adotado pelos poderes Legislativo e Judicial.

Nas palavras de Mello (2009, p. 58) o Direito impõe condutas e que os dispositivos constitucionais "estabelecem comportamentos obrigatórios para o Estado e para os indivíduos". Assim, mesmo as regras programáticas que dispõem sobre a "realização da Justiça Social" atribuem ao Estado brasileiro o "indeclinável dever jurídico de realizá-la".

Nesse diapasão concordam (SALAZAR; GROU, 2009, p. 26) ao afirmarem que

Todas as normas constitucionais concernentes à Justiça Social - inclusive programáticas - geram imediatamente direitos para os cidadãos, inobstante tenham teores eficaciais distintos. Tais direitos são verdadeiros "direitos subjetivos", na acepção mais comum da palavra.

Sobre a eficácia dos direitos sociais, vale mais uma vez lembrar o disposto no art. $5^{\circ}, \S$ $1^{\circ}$, da Constituição Federal, in verbis: "as normas definidoras de direitos fundamentais sejam

\footnotetext{
${ }^{3}$ As normas programáticas consubstanciam programas e diretrizes para atuação futura dos órgãos estatais. Sua função é estabelecer os caminhos que os órgãos estatais, deverão trilhar para ao atendimento da vontade do legislador constituinte, para completar sua obra.
} 
estes civis, políticos, sociais, econômicos ou culturais, possuem eficácia plena e aplicabilidade imediata". (BRASIL, 1988)

O que se depreende dessa doutrina é que as normas constitucionais, assim como todo o ordenamento jurídico brasileiro, possui o caráter imperativo, ou seja, o condão da obrigatoriedade, o que por sua vez, pode ensejar a procura de meios outros, necessários a essa garantia, seja por meio de ações individuais ou coletivas, mas sempre através do Judiciário, que passa a ter papel decisivo e fundamental na concretização das normas constitucionais, visto que a própria Constituição Federal de 1988 traz em seu art. 5º inciso XXXV, o Princípio da Inafastabilidade da Jurisdição, que garante o acesso ao Judiciário quando da lesão ou ameaça a direito.

Assim sendo, quando o indivíduo se sente ameaçado ou sofre alguma lesão a um direito garantido por lei, acaba recorrendo ao direito consagrado na Constituição, isto é, de intentar ação judicial contra o órgão competente para garantir o acesso àquele direito ameaçado ou lesionado. Esse entendimento ganha respaldo na evolução do pensamento jurídico-constitucional, que vê no Ativismo Judicial uma alternativa para o combate à inefetividade das normas constitucionais.

Marcelo Novelino (2008, p. 85/86) reforça essa ideia ao afirmar que

O constitucionalismo contemporâneo decorre de uma nova visão da atitude
interpretativa e das tarefas da ciência e da teoria do direito, preocupadas em
desenvolver um trabalho crítico e não apenas descritivo. [...] o resultado dessa
mudança de paradigma é uma Constituição transformadora que pretende condicionar
as decisões da maioria, tendo como principais protagonistas os juízes e não o
legislador.

Isso significa que a aplicação da Constituição já não depende exclusivamente de uma intermediação legislativa, podendo ocorrer de forma direta, sendo o neoconstitucionalismo, um dos responsáveis por impulsionar o surgimento de uma nova teoria jurídica compatível com o Estado constitucional democrático. (NOVELINO, 2008, p. 86)

Para o constitucionalismo contemporâneo, também chamado de Neoconstitucionalismo, a Constituição Federal não poder ser apenas uma "carta de intenções", mas sim uma realidade sóciolegal sob pena de confrontar-se com sua própria natureza jurídica. Por isso, surge a grande dúvida para o julgador de como proceder diante do fato concreto. 
Nesse caso, a primeira observação a ser feita é a da diferenciação entre regras e princípios, já que a atuação do legislador ou do intérprete judicial dependerá dessa primeira observação. Enquanto que as regras são normas gerais que devem sempre ser cumpridas, em virtude de sua coercitivadade e imperatividade, ou seja, caso se descumpra a determinação por ela imposta a pena cabível será aplicada ao responsável pelo ato, seja por ação ou omissão. Por outro lado, o princípio representa um direito fundamental, um valor, um fim, que pode ser interpretado, sofrendo alterações em face de objetivos maiores, isto é, o princípio não possui essa característica da imperatividade, tornando-se mais flexível, podendo, portanto, se adequar à realidade com base na interpretação do julgador que poderá recorrer à razoabilidade e a proporcionalidade, para aplicar ao caso concreto a melhor solução de modo a preservar os interesses coletivos.

Acontece que, em muitas situações, esses princípios colidem, já que é comum existirem interesses conflitantes dentro da sociedade. É nesse aspecto que cabe a intervenção do legislador, ou na sua omissão, do Judiciário, para dirimir a lide e apresentar a melhor solução possível, de modo que não haja simples demandados, mas, sim, beneficiados pela norma, cada um na sua proporcionalidade.

Conforme os ensinamentos de Barroso L. (2006, p. 6) essa colisão pode se dá de três formas: a) colisão entre princípios constitucionais; b) colisão entre direitos fundamentais; c) colisão entre outros princípios constitucionais e direitos fundamentais.

Quanto à primeira hipótese, podemos citar como exemplo a colisão entre o princípio da livre iniciativa e a proteção do consumidor; já no segundo caso, podemos citar o embate entre o direito à saúde e à vida de um indivíduo e outro, como ocorre nas filas de transplantes, e no último caso, podemos exemplificar através do princípio constitucional da separação de poderes e o direito fundamental à direitos sociais.

Além de entender as espécies de colisão entre princípios e direitos torna-se fundamental a interpretação do constitucionalismo e da democracia quando da aplicação da lei, visto que constitucionalismo significa limitação do poder e supremacia da lei, enquanto que a democracia representa a soberania popular e a vontade da maioria ${ }^{4}$. Por sua vez, os poderes Legislativo, Executivo e Judiciário possuem o dever de promover os direitos fundamentais entre eles os direitos sociais, na maior extensão possível, já que um Estado

\footnotetext{
4 É importante ponderar que a vontade da maioria nem sempre deve ser plenamente atendida, pois quando houver afronta aos direitos fundamentais ou a dignidade da pessoa humana, o Estado deve intervir nessa vontade para defender os direitos e garantias constitucionalmente garantidos.
} 
Democrático, como o Brasil, deve preservar a dignidade da pessoa humana, como pedra basilar da sociedade, ou seja, toda e qualquer decisão deverá preservar a vida, a liberdade, a igualdade, mesmo quando da aparente colisão entre estes direitos e outros princípios democráticos, como a ordem econômica.

Contudo, nem todos os poderes nascem da soberania popular. Apenas o Legislativo e o Executivo representam a democracia, já que foram eleitos através do voto direto, para representarem, num dado período, a vontade da maioria. Por outro lado, o Judiciário é recrutado através de critérios técnicos, mediante a realização de concurso público, e não eletivos, como os demais poderes.

Um grande problema nasce dessa dualidade, isto é, quando há conflitos de interesses, ou violação dos direitos fundamentais, seja através da omissão legislativa ou da inefetividade do executivo, caberá ao judiciário ofertar voto de minerva, e resolver o conflito. Neste contexto, pergunta-se: pode o poder Judiciário interferir na atuação dos outros poderes que representam a democracia? A resposta será afirmativa sempre que os juízes e tribunais, quando de suas decisões, preservarem ou defenderem os direitos fundamentais ou para dar cumprimento a alguma lei existente, ou quando da própria omissão legislativa.

Esse entendimento está previsto nas palavras de Baarroso L. (2006, p. 05) “[...] para que seja legítima, a atuação judicial não pode expressar um ato de vontade própria do órgão julgador, precisando sempre reconduzir-se a uma previa deliberação majoritária, seja do constituinte, seja do legislador".

O Judiciário deve ser chamado a resolver o conflito quando não haja lei regulamentando o caso ou não exista ação administrativa implementando a Constituição. Isso significa que havendo lei e atos administrativos, mas que não estejam sendo devidamente cumpridos devem igualmente os juízes e tribunais intervirem na lide, a fim de garantir o equilíbrio e a paz social. Porém, quando existir lei e atos administrativos, implementando a Constituição, aplicados regularmente, o Judiciário não deve intervir, exceto em casos eventuais sob a égide da autocontenção e não conforme os ideais do Ativismo Judicial cujas definições serão apresentadas a seguir.

\subsection{A JUDICIALIZAÇÃO DA VIDA E O ATIVISMO JUDICIAL}


A redemocratização do país fortaleceu a cidadania e favoreceu a crescente busca pela justiça na sociedade brasileira, através da expansão do Judiciário, do Ministério Público e da Defensoria Pública. Nessa realidade, a população tomou conhecimento de seus direitos individuais e difusos e passou a identificar a ameaça ou violação a que geralmente estava submetida, passando assim, a fazer uso da informação e dos métodos e técnicas disponíveis à concretização de seus direitos, dentre eles os direitos sociais, o que provocou uma crescente busca pela proteção de seus direitos e interesses perante o Judiciário.

Acontece que nem todas as promessas feitas pela democracia foram cumpridas (STRECK; MORAIS, 2010, p. 116), em decorrência de alguns obstáculos supervenientes ao processo democrático, elencando como principais: o problema da legitimação para a tomada de decisões e a dificuldade do Estado para se organizar estrutural e funcionalmente para responder às crescentes demandas sociais.

Por isso, quando a sociedade deparou-se com a realidade fática, e notou o grande abismo existente entre a luta travada pela redemocratização em busca da confirmação de promessas de melhoria na qualidade de vida individual e coletiva e a falta de compromisso dos representantes democráticos para com a concretização dos seus direitos fundamentais, como é o caso dos direitos sociais, decidiu recorrer ao Judiciário, como possível alternativa, para "salvar" seus ideais de vida digna.

Outro fator que influenciou diretamente a judicialização foi a constitucionalização abrangente, ou seja, inúmeras matérias que antes eram deixadas para o processo político majoritário e para a legislação ordinária foi trazida para a Constituição Federal de 1988, com o intuito de transformar Política em Direito. Isso significa que se existe um direito individual, uma prestação estatal ou um fim público, e esse é, de algum modo, violado ou descumprido, é concedido ao indivíduo a formulação de uma ação judicial a fim de obter uma pretensão jurídica, conforme o Princípio da Inafastabilidade, que permite ao Judiciário o debate sobre ações concretas ou a efetivação das políticas públicas, inclusive dos direitos sociais.

É possível identificar a ideia de Clève (2011, p. 58) que alega:

A existência de duas dimensões dos direitos fundamentais: uma subjetiva e outra objetiva. A primeira diz respeito à condição de direitos subjetivos que autorizam o titular a reclamar em juízo determinada ação (omissiva ou comissiva), e a segunda compreende o dever de respeito e compromisso dos poderes constituídos com os direitos fundamentais, aos quais vincula também o Judiciário. 
Outra causa que justifica a judicialização relaciona-se com o sistema brasileiro de controle de constitucionalidade, denominado pela doutrina como híbrido ou eclético.

[...] ele combina aspectos de dois sistemas diversos: o americano e o europeu. Assim, desde o início da República, adota-se entre nós a fórmula americana de controle incidental e difuso, pelo qual qualquer juiz ou tribunal pode deixar de aplicar uma lei, em um caso concreto que lhe tenha sido submetido, caso a considere inconstitucional. Por outro lado, trouxemos do modelo europeu o controle por ação direta, que permite que determinadas matérias sejam levadas em tese e imediatamente ao Supremo Tribunal Federal. A tudo isso se soma o direito de propositura amplo, previsto no art. 103, pelo qual, inúmeros órgãos, bem como entidades públicas e privadas - as sociedades de classe de âmbito nacional e as confederações sindicais - podem ajuizar ações diretas. Nesse cenário, quase qualquer questão política ou moralmente relevante pode ser alçada ao STF. (BARROSO A., 2003, p. 04)

O controle de constitucionalidade consiste na atuação do Judiciário, posterior à edição de uma lei, a fim de impedir a validade dessa norma e, consequentemente, paralisar seus efeitos, retirando-a do ordenamento jurídico em virtude de seu texto afrontar preceitos fundamentais estabelecidos pela Constituição. Conforme Novelino (2008, p. 147), “o controle de constitucionalidade consiste no conjunto de órgãos e instrumentos criados com o objetivo de assegurar a supremacia formal da Constituição".

A Carta Política brasileira representa, numa escala hierarquizada, a norma mais importante para o ordenamento jurídico e para a vida em sociedade, logo toda e qualquer norma infraconstitucional deve atentar, antes de sua edição, para os preceitos fundamentais nela contidos, visto que qualquer afronta aos direitos fundamentais torna essa lei inconstitucional, devendo, portanto ser retirada do seio social.

De acordo com Novelino (2008, p. 150) a inconstitucionalidade decorre do tipo de conduta praticada pelo poder público, logo:

\footnotetext{
A inconstitucionalidade pode ocorrer por ação (decore de conduta positiva contrária a um preceito constitucional) ou omissão (casos em que não sejam praticados os atos legislativos ou executivos necessários para tornar plenamente aplicáveis as normas constitucionais carentes de legislação regulamentadora).
}

Assim sendo, não basta que o poder público, por ação ou omissão, contrarie uma norma constitucional, necessário se faz que dessa ação ou omissão nasça um prejuízo para as partes envolvidas na contenda, cabendo à parte lesada sugerir o exame da constitucionalidade 
daquela norma, com base nas determinações legais, a fim de ver seu direito protegido, bem de como de evitar danos maiores aos envolvidos e a própria coletividade.

Nesse sentido Cunha Jr. (2008, p. 101) assegura que

O exame da constitucionalidade da conduta estatal pode ser agitado, incidenter
tantum, por qualquer das partes envolvidas numa controvérsia judicial, perante
qualquer órgão do Poder Judiciário, independentemente de instância ou grau de
jurisdição, por meio de uma ação subjetiva (ou peça de defesa) ou de um recurso.
Pressupõe a existência de um conflito de interesses, no bojo de uma ação judicial, na
qual uma das partes alega a inconstitucionalidade de uma lei ou ato que a outra
pretende ver aplicada ao caso. Enfim, desde que se possa deduzir uma pretensão
acerca de algum bem da vida ou na defesa de algum interesse subjetivo, pode o
interessado arguir, em sede concreta, a inconstitucionalidade como seu fundamento
jurídico.

O controle de constitucionalidade no Brasil pode ser classificado de diversas formas, variando através dos constitucionalistas, mas quanto à competência do órgão jurisdicional para realizar o controle é uníssono o entendimento de que pode se dar de forma difusa ou concentrada.

A classificação do controle de constitucionalidade, quanto ao seu modo, é prevista, não só, na doutrina, mas na própria lei, pois conforme os artigos 948 a 950 do CPC/2015 (Código de Processo Civil) in verbis: "quanto ao modo difuso ou aberto, os órgãos do Poder Judiciário são competentes para o seu exercício", enquanto que o controle concentrado é reservado ao STF na esfera federal (art. 102, I, a, e $\S 1^{\circ}$ da CF); e no âmbito estadual, aos Tribunais de Justiça (art. 125, $\S 2^{\circ}$ da CF).

Este controle de constitucionalidade, como um dos precursores da judicialização no Brasil concretiza-se através de quatro mecanismos, quais sejam: ação direta de inconstitucionalidade, ação de inconstitucionalidade por omissão, ação declaratória de constitucionalidade e a ação de arguição de descumprimento de preceito fundamental.

Analisa-se agora o Ativismo Judicial como instrumento necessário à efetivação dessa judicialização. Para tanto, entende-se o Ativismo Judicial como a interferência do poder Judiciário no campo de atuação dos poderes Legislativo e Executivo, objetivando a proteção e a concretização das normas constitucionais. Segundo Barroso A. (2003, p. 06) essa postura ativista se manifesta por meio de diferentes condutas, que incluem:

(i) a aplicação direta da Constituição a situações não expressamente contempladas em seu texto e independentemente de manifestação do legislador ordinário; (ii) a declaração de inconstitucionalidade de atos normativos emanados do legislador, com base em critérios menos rígidos que os de patente e ostensiva violação da 
Constituição; (iii) a imposição de condutas ou de abstenções ao Poder Público, notadamente em matéria de políticas públicas.

Isso significa que a atuação do Judiciário não incide em qualquer situação ou conforme o querer dos seus membros, mas mediante a necessidade social de resposta às suas indagações decorrentes da evolução social, principalmente quando a Constituição for omissa, ou quando o legislador ordinário na intenção de preencher uma lacuna constitucional estabelecer uma norma que fira os preceitos fundamentais e ofereça ostensiva violação ao texto constitucional, ou ainda, quando o poder público se negar a executar as políticas públicas, como é o caso dos direitos sociais.

Em contrapartida existe a autocontenção judicial, que pode ser entendida como a minimização da interferência do poder Judiciário nas ações dos outros poderes, de modo a preservar o princípio fundamental da tripartição de poderes, garantida pela Constituição Federal de 1988. (BARROSO A., 2003)

Corroborando esse entendimento Posner (2010, p. 45) afirma que "a autoconstrição judicial, no sentido de hesitação em derrubar as decisões de outros ramos do governo, pode ser parte da concepção que o juiz tem da boa sociedade”. Por isso, é importante sopesar os benefícios e as perdas advindas da proliferação do Ativismo Judicial e do desenvolvimento da autocontenção, visto que, enquanto o primeiro busca melhorar o ordenamento jurídico pátrio através da análise das potencialidades contidas no texto constitucional sem, contudo, criar normas (já que essa é função típica do Legislativo), o segundo quer "restringir o espaço de incidência da Constituição em favor das instâncias tipicamente políticas". (BARROSO A., 2003, p. 07)

Diante dessa dualidade de pensamentos, onde grande parte acredita ser o Ativismo Judicial necessário à concretização dos direitos sociais, enquanto os demais defendem o desenvolvimento da autocontenção como melhor alternativa, por acreditarem que a intromissão do judiciário na esfera dos outros poderes representa uma afronta à Constituição Federal, percebe-se necessária uma pausa para reflexão quanto à dogmática dos direitos sociais, ou seja, a análise imprescindível das dimensões dos direitos fundamentais constitucionalmente garantidos, mas não efetivados.

\subsection{A DOGMÁTICA DOS DIREITOS SOCIAIS}


Com o intuito de justificar a decisão tomada pelo Judiciário no momento da colisão apresentada faz-se necessária a ponderação dos direitos envolvidos na lide, diferenciando os direitos sociais dos direitos individuais com base nas dimensões dos direitos fundamentais e nas concepções de existência desses direitos.

Nesta esteira de pensamento, abre-se um parêntese nessa discussão, para informar o pensamento de Esteves (2007, p. 40), segundo o qual existem duas concepções quanto à existência desses direitos, uma restritiva e outra ampliativa. A restritiva decorre do pensamento de Torres (1999, p. 40), que diz: "os direitos sociais somente existem como condição para o exercício dos direitos de liberdade". É possível justificar essa tese com base no dever que o Estado tem de garantir o mínimo existencial a todos, já que sem o mínimo necessário à existência cessa a possibilidade de sobrevivência do homem e desaparecem as condições iniciais da liberdade. Todavia, existe outra corrente que enxerga limites à garantia desse "mínimo existencial", sendo Barcellos (2002) adepta dessa teoria, que por sua vez entende que há restrição aos direitos sociais, inclusive limitando o "mínimo existencial" à tese de uma "reserva do possível" vinculada à existência de um orçamento. (ESTEVES, 2007, p. 42)

Assim sendo, é possível concluir que conforme a concepção restritiva de direitos, o Estado tem o dever de efetivar os direitos sociais previstos na Constituição Federal, mediante o atendimento ao "mínimo existencial", ou seja, ao atendimento das necessidades básicas de todo e qualquer indivíduo independentemente de sua condição física, psíquica ou financeira, mas esse atendimento deve estar limitado à "reserva do possível", que representa a existência de um orçamento previamente elaborado para aplicar os recursos captados de acordo com as diretrizes contidas no orçamento.

Já a concepção ampliativa de direitos, que tem como defensor José Carlos Vieira de Andrade, é aquela que entende ser necessária a restrição dos direitos individuais para, assim, assegurar a realização ou a proteção de direitos econômicos, sociais e culturais. (ESTEVES, 2007, p. 44)

A dignidade da pessoa humana deve nortear todas as decisões judiciais, pois nesse sentido tem-se a certeza de que não haverá violação à vida, já que os direitos fundamentais serão preservados, visto que os direitos humanos não nascem de uma única vez nem tampouco representa uma ideologia utópica, mas urgente e necessária na sociedade 
contemporânea, que presencia a todo instante grandes violações às normas morais, éticas e jurídicas, que por sua vez trazem em seu bojo a essência da humanidade.

\begin{abstract}
Os direitos humanos não nascem todos de uma vez, eles são históricos e se formulam quando e como as circunstâncias sócio-histórico-políticas são propícias ou referem a inexorabilidade do reconhecimento de novos conteúdos, podendo-se falar, assim, em gerações de direitos humanos, cuja primeira estaria ligada aos direitos civis e políticos - as liberdades negativas -, uma segunda geração atrelada aos conteúdos das liberdades positivas, como os econômicos, sociais e culturais, e uma terceira vinculando as questões que afligem os homens em conjunto, como os relativos à paz, ao desenvolvimento, ao meio ambiente, etc. (BOBBIO, 1992, p. 06)
\end{abstract}

Como ponderado anteriormente, a aplicabilidade das normas constitucionais deve ser imediata, já que a Constituição Federal $\left(\S 1^{\circ}\right.$ do art. $\left.5^{\circ}\right)$ não representa, apenas, uma "carta de intenções" vinculada ao bel prazer dos agentes políticos, onde os direitos sociais se tornariam efetivos, somente, quando existisse no orçamento recursos disponíveis para a sua implementação. Porém, a grande discussão envolve qual órgão é competente para tornar essas normas efetivas, sem privilegiar um direito em detrimento do outro, pois como foi analisado nenhum direito é mais ou menos importante que outro.

Por esse motivo, as críticas à judicialização excessiva na busca pelo acesso aos direitos sociais, bem como as mudanças provocadas pela atuação do Judiciário na vida das pessoas e na sociedade devem sem analisados.

\title{
3.4 OBJEÇÕES À CRESCENTE INTERVENÇÃO JUDICIAL NOS DIREITOS SOCIAIS
}

Segundo Barroso L. (2006, p. 08) três objeções podem ser opostas à judicialização e, sobretudo, ao ativismo judicial no Brasil. Nenhuma delas infirma a importância de tal atuação, mas todas merecem consideração. As críticas se concentram nos riscos para a legitimidade democrática, na politização indevida da justiça e nos limites da capacidade institucional do Judiciário. Essa intervenção está amparada pelo binômio "mínimo existencial" e "reserva do possível".

Quanto aos riscos para a legitimidade democrática deve-se lembrar que os juízes não foram eleitos pelo povo como os membros do legislativo e do executivo, por isso questiona-se de onde provêm o seu direito de tomarem decisões contrárias aos membros dos outros poderes, vindo inclusive a anular seus atos e vontade.

De acordo com o pensamento neoconstitucional há duas justificativas para essa intervenção, a primeira é a normativa, isto é, a própria Constituição Federal prevê e assegura 
essa intervenção dos agentes públicos nas decisões políticas, sendo, portanto, o Judiciário convocado para exercer o seu papel de intérprete e julgador da lei, já que os juízes e tribunais não possuem apenas um papel mecânico, mas são coparticipantes do processo de criação do Direito.

A segunda justificativa é de caráter filosófico, que por sua vez encontra respaldo em um dos pilares do Estado de Direito, onde a democracia representa a vontade da maioria e o Constitucionalismo defende o limite do poder e a preservação e garantia dos Direitos Fundamentais, ou seja, quando a vontade da maioria for contrária à Constituição ou violar qualquer direito fundamental, aquela não prevalecerá.

Com isso é possível afirmar que o Ativismo Judicial bem exercido é antes uma garantia para democracia do que um risco, visto que o Judiciário, através do STF, deve ser deferente para com as deliberações do Congresso, preservando a democracia e os direitos fundamentais, de modo a não suprimir o papel do Legislativo.

Enquanto isso, o risco de politização da justiça representa outra objeção à judicialização, no Brasil, podendo ser entendida como o temor de transformar a justiça social em política. Nesse sentido, é importante compreender que o Direito não é política, já que em uma cultura pós-positivista, o Direito se aproxima da Ética, tornando-se instrumento da legitimidade, da justiça e da realização da dignidade da pessoa humana.

Assim fica evidente que o Direito não é Política, já que esta é a maior inimiga do Constitucionalismo, pois esse não admite escolhas livres, tendenciosas, padronizadas ou de discricionariedade plena. Essa característica é facilmente identificada quando o juiz se depara com uma situação, que em tese, comporta mais de uma solução, devendo, portanto, o juiz aplicar aquela que favoreça a justiça, a paz e o equilíbrio social, mediante o emprego de argumentação racional e convincente, já que todas as decisões dos juízes devem ser motivadas, o que por sua vez garante específica legitimação.

Cabe reavivar os ideários de Binenbojm (2010, p. 60) que assim infere:

Só deve agir em nome da Constituição e das leis, e não por vontade política própria; deve ser deferente para com as decisões razoáveis tomadas pelo legislador, respeitando a presunção de validade das leis; não deve perder de vista que, embora não eleito, o poder que exerce é representativo (emana do povo e em seu nome deve ser exercido), razão pela qual sua atuação deve estar em sintonia com o sentimento social, na medida do possível. Aqui, porém, há uma sutileza: juízes não podem ser populistas e, em certos casos, terão de atuar de modo contramajoritário. A conservação e a promoção dos direitos fundamentais, mesmo contra a vontade das maiorias políticas, é uma condição de funcionamento do constitucionalismo 
democrático. Logo, a intervenção do Judiciário, nesses casos, sanando uma omissão legislativa ou invalidando uma lei inconstitucional, dá-se a favor e não contra a democracia.

Em contrapartida é possível asseverar que a intervenção do Judiciário, não caracteriza uma politização do direito, mas, sim, um órgão auxiliar da democracia, que serve como contrapeso nas decisões dos outros poderes, que não agem livremente segundo seu desejo (a vontade da maioria), pois serão submetidos ao aval de juízes, desembargadores e ministros, que por sua vez, sanarão as omissões legislativas e tornarão inválidas as leis inconstitucionais, com o objetivo único de conservar e promover os direitos fundamentais.

Por fim, deve-se analisar a capacidade institucional do Judiciário e seus limites, já que o Brasil adota o princípio da separação de poderes proposta por Montesquieu, em o espírito das Leis. E o próprio art. $2^{\circ}$ da Constituição Federal aduz que "são Poderes da União, independentes e harmônicos entre si, o Legislativo, o Executivo e o Judiciário", o que corrobora a ideia de que os poderes são independentes em suas respectivas esferas de atuação, e devem ser equilibrados, respeitando seus limites e evitando interferir um no outro, de modo que entre eles haja equilíbrio, a fim de se evitar a supremacia de qualquer deles sobre outro.

É aconselhável que o poder mais habilitado, com mais gabarito para causa seja responsável por emitir a decisão final no caso, e não apenas restringir essa aptidão ao Judiciário, já que em muitos casos, os juízes não possuem o conhecimento necessário das consequências de sua decisão e acaba colocando em risco o acesso e a concretização de outros direitos, como é o caso da judicialização dos direitos sociais, pois o juiz está preparado para realizar a microjustiça, isto é, atender a tutelas específicas, colocando em risco a própria continuidade das políticas públicas, que deverão relocar os recursos financeiros de um setor para outro.

Quanto a este tema preleciona Posner (2010, p. 58) que a melhor solução é acabar com a ideia de separar formulação de políticas públicas do trabalho judicial. Ele, que é juiz federal, disse que diante de casos difíceis, a decisão do julgador não tem como não passar pela análise de políticas públicas. O resultado final seria, na verdade, uma escolha entre políticas públicas possíveis.

O juiz deve fazer uma escolha entre políticas públicas, e a escolha ditada pelos resultados do levantamento e da avaliação das consequências das opções alternativas: consequências para o Estado de Direito, para as partes, para a 
economia, para a ordem pública, para a civilização, para o futuro, em suma, para a sociedade. (POSNER, 2010, p. 37)

Isto significa que a atuação do juiz, é possível sim, porém ele não deve tomar a decisão com base apenas no caso específico, mas deve analisar toda a conjuntura envolvida, ou seja, quais as consequências dessa sua decisão, tanto para as partes envolvidas (microjustiça), quanto para os outros direitos econômicos, sociais, políticos e culturais. Pois, é notório para o direito que os efeitos de uma sentença se estende à coletividade, atingindo todos os outros setores da sociedade, podendo trazer melhorias ou retrocessos.

Outra característica do poder Judiciário é a discricionariedade, a qual concede ao juiz a liberdade de interpretar as normas e aplicá-las ao caso concreto, fazendo uma análise dos fatos e das leis que regulamenta a situação. Acontece que nestes casos, muitas vezes, os juízes não atentam para os reflexos de sua decisão na sociedade, que poderá interferir na vida de outrem. Além do que, essa discricionariedade pode gerar sentenças diversas para casos semelhantes, pois cada ser humano possui características próprias, e como os juízes não são máquinas que apenas reproduzem ideias, mas são seres pensantes, no momento de tomarem suas decisões, podem chegar a resultados diferentes.

Senão vejamos o pensamento de Posner (2010, p. 62) "Em todos os níveis do Judiciário, os juízes exercem poder discricionário, o que quer dizer que dois juízes diferentes, ao encararem a mesma questão, podem chegar a diferentes resultados sem que nenhum dos dois seja reformado".

Nesse diapasão, pode-se afirmar que a busca pelo Judiciário não é a melhor solução para os direitos sociais, até porque como ponderado anteriormente, a judicialização realiza uma microjustiça, quando na verdade o problema dos direitos sociais é mais amplo, necessitando de uma política pública bem elaborada para que seja eficiente. Acrescente a informação de que a judicialização do acesso aos direitos sociais não traz benefícios diretos e/ou concretos para a sociedade, podendo oferecer respostas imediatas àqueles envolvidos na demanda, o que caracteriza uma colisão de direitos, pois enquanto o direito de um é garantido por determinação judicial, outros são renegados, já que a "reserva do possível" não é capaz de garantir a execução de todos os direitos individuais e coletivos.

\section{CONCLUSÃO}


Para cumprir adequadamente a sua função a democracia necessita resguardar um princípio fundamental: permitir que cada pessoa se sinta ativamente participante na construção das políticas públicas. Os instrumentos utilizados devem promover o pluralismo, estabelecendo espaços de diálogo destinados à representação das questões éticas e normativas.

A democracia deve assegurar, com atenção especial, os direitos elementares que correspondam à consciência de um universo ético no qual a pessoa age. Particularmente, essa correta concepção do universo ético deve orientar para a abertura de horizontes do bem comum, progressivamente mais amplos, até englobar toda a família humana.

Os fatores reais de poder, por meio do progresso científico e tecnológico, têm mostrado, nestes últimos anos, como as escolhas feitas no presente podem influenciar o estilo de vida e, em alguns casos, a própria existência dos humanos e das futuras gerações. As pessoas de hoje, de fato, devem ser solidários com os seus contemporâneos - onde quer que estejam - mas também com os futuros habitantes do planeta. É preciso perceber que há necessidade de formar lideranças que apontem caminhos, procurando dar respostas às necessidades atuais, todos incluídos, sem prejudicar o outro, razão pela qual a tarefa da democracia é contribuir para a construção dessa cultura baseada na ética intergeracional.

Por isso, pode-se afirmar que a democracia brasileira está ameaçada, seja pela omissão dos poderes legislativo e executivo, ou seja pelo excesso de atuação do STF, que em tese, deveria proteger e conduzir toda sua atuação com base na Constituição Federal de 1988. A perda da credibilidade dos agentes políticos, eleitos democraticamente, pela maioria, aliada a exacerbada judicialização das demandas sociais e dos direitos fundamentais, comprovam a diminuição da cultura de paz e o aumento dos conflitos.

Além disso, a representatividade, na democracia exige a participação de todos, seja na eleição dos seus representantes, seja na discussão ou na atuação direta de todos os grupos sociais, incluídos, a maioria e a minoria. O indivíduo é parte do todo e a sociedade representa o conjunto dessa totalidade, mas que para seja, de fato, democrática, precisa garantir o acesso aos direitos fundamentais e sociais, e esse acesso começa com a participação dos indivíduos nos espaços de discussão e de poder.

Por fim, a busca pelo Judiciário não tem sido a melhor solução para as questões sociais, até porque a judicialização realiza uma microjustiça, enquanto a problemática dos direitos sociais é macro, necessitando de uma atuação conjunta de todos os poderes. Além disso, como visto, o ativismo judicial e a interferência do STF, na condução das políticas 
públicas, não têm trazido benefícios concretos para a sociedade, mas tão-somente medidas paliativas às partes envolvidos no litígio judicial, o que caracteriza uma colisão de direitos e uma grave ameaça a democracia, pois enquanto o direito de um é garantido por determinação judicial, outros são renegados, já que a "reserva do possível" não é capaz de garantir a execução de todos os direitos individuais e coletivos.

\section{REFERÊNCIAS}

BARCELlOS, A. P. de. A eficácia jurídica dos princípios constitucionais. Rio de janeiro: Renovar, 2002.

BARROSO, A. F. Aspectos relacionados à efetivação do direito à direitos sociais no Brasil através do poder judiciário. Rio de Janeiro: ENSP/FIOCRUZ, 2003.

. Direito à Direitos sociais no Brasil através do Poder Judiciário. Rio de Janeiro:

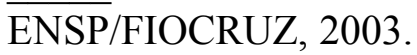

BARROSO, L. R. O Direito Constitucional e a efetividade de suas normas. Limites e possibilidades da Constituição brasileira. Rio de Janeiro: Renovar, 2006.

BINENBOJM, G. A nova jurisdição constitucional brasileira: Legitimidade democrática e Instrumentos de realização. Rio de Janeiro: Renovar, 2010.

BOBBIO, N. A Era dos Direitos. Rio de Janeiro: Campus, 1992.

CLÈVE, C. M. Constituição, Democracia e Justiça: aportes para um constitucionalismo igualitário. Belo Horizonte: Editora Fórum, 2011.

CUNHA JR, D. da. Controle de constitucionalidade: teoria e prática. Salvador: Jus Podivm, 2008.

ESTEVES, J. L. M. Direitos fundamentais sociais no Supremo Tribunal Federal. São Paulo: Ed. Método, 2007.

HESSE, K. Conceito e peculiaridade da Constituição. Tradução: Inocêncio Mártires Coelho. In: HESSE, K. Temas Fundamentais do Direito Constitucional. São Paulo: Saraiva, 2009.

A força normativa da constituição. Trad. Gilmar Ferreira Mendes. Porto Alegre: Sergio Antonio Fabris, 1991.

KANT, I. Crítica da razão pura. 3. ed. Petrópolis, RJ; Bragança Paulista, SP: Vozes: Ed. Universitária São Francisco, 2012.

KELSEN, H. Teoria pura do direito. Tradução de João Baptista Machado. São Paulo: Martins Fontes, 2006. 
LASSALLE, F. A essência da constituição. Rio de Janeiro: Lumem Iuris, 2000.

LEVITSKY, S.; ZIBLATT, D. Como as democracias morrem. Trad. Renato Aguiar. Rio de Janeiro: Ed. Zahar, 2018.

MELLO, C. A. B. de. Eficácia das normas constitucionais e direitos sociais. São Paulo: Malheiros, 2009.

MILL, J. S. Considerações sobre o governo representativo. Trad. Manoel Inocêncio de Lacerda Santos Jr. Brasília: Universidade de Brasília, 1981.

NOVELINO, M. Teoria da constituição e controle de constitucionalidade. Salvador: Jus Podivm, 2008.

PLATÃO. A República. Trad. Maria Helena da Rocha Pereira. Lisboa: Fundação Calouste Gulbenkian, 1987.

POPPER, K. R. A sociedade aberta e seus inimigos: o fascínio de Platão. $3^{\text {a }}$ ed. Trad. Milton Amado. Belo Horizonte: Itatiaia, 1988.

POSNER, R. Direito, pragmatismo e democracia. Tradução de Teresa Dias Carneiro. Revisão técnica de Francisco Bilac. M. Pinto Filho. Rio de Janeiro: Forense, 2010.

SALAZAR, A. L.; GROU, K. B. A defesa da direitos sociais em juízo. São Paulo: Verbatim, 2009.

SARLET, I. W. A eficácia dos direitos fundamentais: uma teoria geral dos direitos fundamentais na perspectiva constitucional. Porto Alegre: Livraria do advogado, 2010.

SCHUMPETER, J. A. Socialismo e democracia. In: Capitalismo, socialismo e democracia. Trad. Sergio Góes de Paula. Rio de Janeiro: Zahar, 1984.

STRAUSS, L. La filosofia como ciência estricta y la filosofia politica; Sobre la ley natural; Jerusálen y atenas: algunas reflexiones. In: Estudios de filosofia política platônica. Trad. Amelia Aguado. Buenos Aires: Amorrortu, 2008.

STRECK, L. L.; MORAIS, J. L. B. de. Ciência Política \& Teoria do Estado. Porto Alegre: Livraria do Advogado, 2010.

TALMON, J. L. Los origines de la democracia totalitária. Trad. Manuel Cardenal Iracheta. México: Aguillar, 1956.

TOCQUEVILlE, A. de. A democracia na América. Trad. Eduardo Brandão. São Paulo: Martins Fontes, 2014.

TORRES, R. L. Teoria dos Direitos Fundamentais. Rio de Janeiro: Renovar, 1999. 
WEICHERT, M. A. Direitos sociais e Federação na Constituição Brasileira. Lumen Juris: Rio de Janeiro, 2004.

WEIS, C. Os direitos humanos contemporâneos. São Paulo: Malheiros, 2010. 